\title{
Elaiomycins B and C, novel alkylhydrazides produced by Streptomyces sp. BK 190*
}

\author{
Byung-Yong Kim ${ }^{1}$, Stefanie Willbold ${ }^{2}$, Andreas Kulik², Soleiman E Helaly ${ }^{3,5}$, Heidi Zinecker ${ }^{4}$, Jutta Wiese ${ }^{4}$, \\ Johannes F Imhoff ${ }^{4}$, Michael Goodfellow ${ }^{1}$, Roderich D Süssmuth ${ }^{3}$ and Hans-Peter Fiedler ${ }^{2}$
}

The Journal of Antibiotics (2011) 64, 595-597; doi:10.1038/ja.2011.53; published online 20 July 2011

Keywords: alkylhydrazides; azoxy antibiotic; elaiomycin; Streptomyces; taxonomy

Dereplicated novel actinomycetes from neglected habitats provide high quality biological material for screening programs designed to detect novel bioactive secondary metabolites. ${ }^{2}$ Such organisms include neutrotolerant acidophilic streptomycetes which grow from $\mathrm{pH} 4.5$ to 7.5, with an optimum between $\mathrm{pH} 5.0$ and $5.5 .^{3}$ Members of this group were isolated from a hay meadow soil taken from Cockle Park Experimental Farm in Northumberland, UK. The isolates were grown as submerged cultures in complex media, and extracts from the culture filtrates and mycelia included in our HPLC-diode array screening program to detect novel secondary metabolites by means of an in-house HPLC-UV-Vis database, which contains approximately 950 natural products, mainly antibiotics. ${ }^{4}$ Strain BK 190 was of interest because of the presence of three prominent peaks in the HPLC profile of a culture filtrate extract. The strain was assigned to the genus Streptomyces by its morphological and chemotaxonomic properties. ${ }^{5}$ Strain BK 190 formed an extensively branched substrate mycelium, a grey aerial spore mass and aerial hyphae, which differentiated into spiral chains of smooth-surfaced spores on oatmeal agar, contained LL-diaminopimelic acid, galactose, glucose and xylose as major sugars, $\mathrm{N}$-acetylated muramic acid, predominant amounts of hexa- and octa-hydrogenated menaquinones with nine isoprene units, and produced iso- and anteiso-branched fatty acids with $\mathrm{C}_{15: 0}$ and iso- $\mathrm{C}_{16: 0}$ as major components. The temperature and $\mathrm{pH}$ ranges for growth were $10-35^{\circ} \mathrm{C}$ and $\mathrm{pH} 4.0-8.0$, respectively. Phylogenetic analyses showed that the organism was most closely related to the type strain of Streptomyces sanglieri; the two organisms shared a $16 \mathrm{~S}$ rRNA similarity of $99.9 \%$, a value that corresponds to a single nucleotide difference at 1434 locations.

The metabolite with retention time of $12.3 \mathrm{~min}$ in our standardized reversed-phase gradient elution profile was identified by HPLC-diode array and HPLC-ESI-MS analysis to be elaiomycin (1), an azoxy antibiotic that was first isolated from Streptomyces hepaticus and found to strongly inhibit the growth of Mycobacterium tuberculosis. ${ }^{6}$ Two further prominent peaks, elaiomycin B (2) with a retention time of $16.4 \mathrm{~min}$, and elaiomycin C (3) with a retention time of $17.2 \mathrm{~min}$ showed characteristic UV-vis spectra that differed from those of all of the reference compounds stored in the database. A significant production of 1-3 was observed in oatmeal medium in the $100 \mathrm{ml}$ shake flask scale, which was reproducible in a scale up to a 20-liter fermentor. Strain BK 190 reached a maximal biomass of 12 volume (\%) at a cultivation time of $96 \mathrm{~h}$ and this correlated with the highest production of elaiomycins, which reached yields of $24 \mathrm{mgl}^{-1}$ elaiomycin (1), $15 \mathrm{mgl}^{-1}$ elaiomycin B (2) and $9.5 \mathrm{mgl}^{-1}$ elaiomycin $\mathrm{C}(3)$ in the culture filtrate, and $15 \mathrm{mgl}^{-1}$ of 2 and $12 \mathrm{mgl}^{-1}$ of 3 in the mycelium, respectively. Compounds 1-3 were isolated from the culture filtrate by separation on an Amberlite XAD-16 column (Rohm and Haas Deutschland, Frankfurt, Germany), followed by extraction with ethyl acetate. Compounds $\mathbf{2}$ and $\mathbf{3}$ were also isolated in remarkable amounts from the mycelium by extraction. The crude product was purified by subsequent chromatography on diol-modified silica gel and Sephadex LH-20 (Amersham, Freiburg, Germany). Pure compounds 1, 2 and 3 were obtained by preparative reversed-phase HPLC, 1 resulted as a colorless oil, $\mathbf{2}$ and $\mathbf{3}$ as white powders. The physico-chemical properties of compounds $\mathbf{1} \mathbf{- 3}$ are summarized in Table $\mathbf{1}$. They are soluble in methanol, ethylacetate, dichloromethane and cyclohexane. Detailed informations on structure determination were reported by Helaly et al. ${ }^{7}$ Compounds $\mathbf{2}$ and $\mathbf{3}$ contain a hydrazide chromophore as the characteristic structural element, as shown in Figure 1.

Antimicrobial assays were performed as recently described by Schneemann et al. ${ }^{8}$ Compounds $\mathbf{2}$ and $\mathbf{3}$ were slightly active against Staphylococcus lentus DSM 6672. Growth inhibition of $23 \%$ and $24 \%$, respectively, was observed at a concentration of $100 \mu \mathrm{M}$. No antibiotic activity was found against Bacillus subtilis DSM 347, Propionibacterium acnes DSM 1897T or Xanthomonas campestris DSM 2405.

${ }^{1}$ School of Biology, University of Newcastle, Newcastle Upon Tyne, UK; ${ }^{2}$ Mikrobiologisches Institut, Universität Tübingen, Tübingen, Germany; ${ }^{3}$ Institut für Chemie, Technische Universität Berlin, Berlin, Germany; ${ }^{4}$ Kieler Wirkstoff-Zentrum am Leibniz-Institut für Meereswissenschaften, IFM-GEOMAR, Kiel, Germany and ${ }^{5}$ Department of Chemistry, Faculty of Science, South Valley University, Aswan, Egypt

Correspondence: Professor Dr H-P Fiedler, Mikrobiologisches Institut, Universität Tübingen, Auf der Morgenstelle 28, 72076 Tübingen, Germany.

E-mail: hans-peter.fiedler@uni-tuebingen.de

*Art. No. 55 in 'Biosynthetic Capacities of Actinomycetes'. Art. No. 59: see ref. 1.

Received 19 January 2011; revised 21 April 2011; accepted 26 April 2011; published online 20 July 2011 
Table 1 Physico-chemical properties of elaiomycin (1), elaiomycin B (2) and elaiomycin C (3)

\begin{tabular}{|c|c|c|c|}
\hline & 1 & 2 & 3 \\
\hline Appearance & Colorless oil & White powder & White powder \\
\hline Molecular mass $\left(\mathrm{g} \mathrm{mol}^{-1}\right)$ & 258.1 & 478.5 & 476.5 \\
\hline \multicolumn{4}{|l|}{ High-resolution orbitrap-ESI-MS $\left(m z^{-1}\right)$} \\
\hline Found & $259.20077[\mathrm{M}+\mathrm{H}]^{+}$ & $479.42053[\mathrm{M}+\mathrm{H}]^{+}$ & $477.40483[\mathrm{M}+\mathrm{H}]^{+}$ \\
\hline$[\alpha]_{D}^{23}(c, 2.8, \mathrm{EtOH})$ & +33.2 & - & - \\
\hline IR $v_{\max }\left(\mathrm{cm}^{-1}\right)$ & $\begin{array}{c}3450,2957,2926,2857,1467 \\
1373,1303,1117,786\end{array}$ & $\begin{array}{c}3267,2954,2925,2855,1692 \\
1466,1379,1117,723\end{array}$ & $\begin{array}{c}3273,2953,2924,2854,1693 \\
1466,1387,1117,723\end{array}$ \\
\hline
\end{tabular}
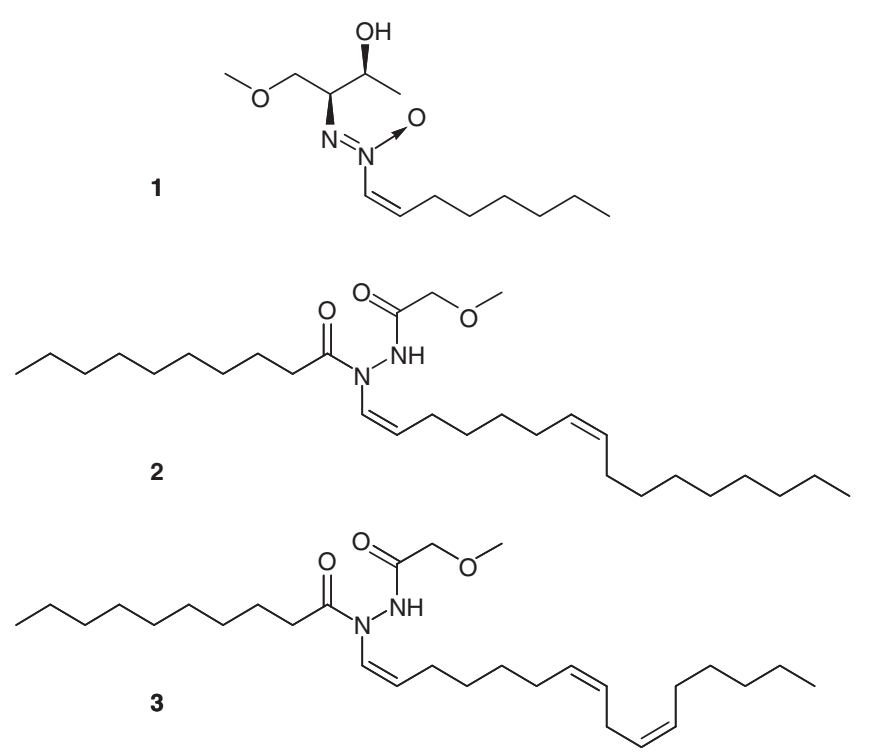

Figure 1 Structures of elaiomycin (1), elaiomycin B (2) and elaiomycin C (3).

Compound 1 did not show an antibacterial activity. Enzyme inhibition assays showed an inhibitory activity of compounds 2 and 3 against acetylcholinesterase $\left(\mathrm{IC}_{50}=1.0 \mu \mathrm{M}\right.$ and $\mathrm{IC}_{50}=2.0 \mu \mathrm{M}$, respectively) and phosphodiesterase (PDE- $4 \mathrm{~B} 2 ; \mathrm{IC}_{50}=6.5 \mu \mathrm{M}$ and $\mathrm{IC}_{50}=$ $8.0 \mu \mathrm{M}$, respectively) in contrast to elaiomycin (1), which was not active in both assays. Compounds $2(50 \mu \mathrm{M})$ and $3(50 \mu \mathrm{M})$ did not show cytotoxic activity towards tumor cell lines HepG2 and HT29, whereas a moderate inhibition of the cell line HepG2 was observed for elaiomycin (1) $\left(\mathrm{IC}_{50}=16.3 \mu \mathrm{M}\right)$.

Besides elaiomycin, only a few antibiotics containing an azoxy chromophore have been described; these include: antibiotic LL-BH872 $\alpha,{ }^{9}$ maniwamycins $A$ and $B^{10}$ and azoxybacilin ${ }^{11}$ (all show strong antifungal activity); valanimycin, which shows antitumor and antibacterial activity; ${ }^{12}$ and jietacins $\mathrm{A}$ and $\mathrm{B}$, which exhibit a pronounced nematocidal and weak antifungal activity. ${ }^{13}$ In contrast to azoxy-containing compounds, naturally occurring hydrazines and hydrazides are rarely described. Only two fungal metabolites have been reported, agaritine from the cultivated mushroom Agaricus bisporus ${ }^{14}$ and gyromitrin from the false morel Gyromitra esculenta. ${ }^{15}$ As far as we know, elaiomycins B (2) and C (3) are the first natural occurring alkylhydrazides with therapeutic potential as shown by their inhibitory activity against clinically relevant enzymes.

\section{EXPERIMENTAL PROCEDURE}

\section{Producing organism and classification}

Strain BK190 was isolated from a soil sample collected from Palace Leas hay meadow plot 6 at Cockle Park Experimental Farm, Northumberland, UK (National Grid Reference NZ 200913). The microorganism was examined for chemotaxonomic and morphological properties known to be useful in the systematics of Streptomyces. ${ }^{5}$ The 16S rRNA gene amplification and sequencing were carried out using an established method ${ }^{16}$ and the resultant, almost complete sequence, compared with corresponding sequences of related Streptomyces using the MEGA 4.0 software. ${ }^{17}$ Phylogenetic trees were inferred by using the neighbour-joining tree-making algorithm. ${ }^{18}$

\section{Fermentation and isolation}

Batch fermentations of strain BK 190 were carried out in a 20-1 fermentor, equipped with a turbine impeller system (b20; B. Braun, Melsungen, Germany) in a complex medium which consisted of (per liter tap water) oatmeal (Holo Hafergold, Neuform, Germany) $20 \mathrm{~g}$ and $5 \mathrm{ml}$ of a trace element solution composed of (per liter deionized water) $\mathrm{CaCl}_{2} \cdot 2 \mathrm{H}_{2} \mathrm{O} 3 \mathrm{~g}$, iron (III) citrate $1 \mathrm{~g}$, $\mathrm{MnSO}_{4} \cdot \mathrm{H}_{2} \mathrm{O} 200 \mathrm{mg}, \mathrm{ZnCl}_{2} 100 \mathrm{mg}, \mathrm{CuSO}_{4} \cdot 5 \mathrm{H}_{2} \mathrm{O} 25 \mathrm{mg}, \mathrm{Na}_{2} \mathrm{~B}_{4} \mathrm{O}_{7} \cdot 10 \mathrm{H}_{2} \mathrm{O}$ $20 \mathrm{mg}, \mathrm{CoCl}_{2} \cdot 6 \mathrm{H}_{2} \mathrm{O} 4 \mathrm{mg}$ and $\mathrm{Na}_{2} \mathrm{MoO}_{4} \cdot 2 \mathrm{H}_{2} \mathrm{O} 10 \mathrm{mg}$; the $\mathrm{pH}$ was adjusted to $7.3(5 \mathrm{M} \mathrm{HCl})$ prior to sterilization. The fermentation was carried out for $96 \mathrm{~h}$ with an aeration rate of 0.5 -volume air per volume per min and agitation at 1000 r.p.m.

Compounds 1-3 were isolated from the culture filtrate by Amberlite XAD-16 column chromatography (resin vol 21) and were eluted with $\mathrm{MeOH}$. The concentration was extracted three times with EtOAc and concentrated in vacuo to dryness $(325 \mathrm{mg})$. The mycelium, which contained 2 and $\mathbf{3}$, was extracted twice with $\mathrm{MeOH}-\mathrm{Me}_{2} \mathrm{CO}$ (1:1); the extracts were combined, concentrated in vacuo to an aqueous residue and re-extracted three times with EtOAc. The crude product $(7.36 \mathrm{~g})$ was dissolved in $\mathrm{CH}_{2} \mathrm{Cl}_{2}$ and applied to a diol-modified silica gel column (E. Merck, Darmstadt, Germany). Compounds 1-3 were separated by a linear gradient from $\mathrm{CH}_{2} \mathrm{Cl}_{2}$ to $\mathrm{CH}_{2} \mathrm{Cl}_{2}-\mathrm{MeOH}(9: 1)$. Further purification was achieved by chromatography on Sephadex LH-20 (Amersham) with $\mathrm{MeOH}$ as eluent. Fractions containing $\mathbf{2}$ and $\mathbf{3}$ were separated to pure compounds by prep RP-HPLC (Nucleosil-100 C-18, 20×250 mm; Maisch, Ammerbuch, Germany) and elution with $\mathrm{MeOH}-\mathrm{H}_{2} \mathrm{O}$ (95:5). After concentrating to dryness in vacuo, elaiomycin (1) was obtained as colourless oil, whereas elaiomycins B (2) and C (3) were obtained as white powders.

\section{Cytotoxic assays}

The sensitivity of the cell lines NIH-3T3, HepG2 and HT-29 to the isolated compounds was evaluated by monitoring of the metabolic activity using the CellTiter-Blue Cell Viability Assay (Promega, Mannheim, Germany). 
The cultivation of the cell lines and the bioassays were performed as described by Schneemann et al. ${ }^{8}$

\section{Enzyme inhibition assays}

The determination of the acetycholinesterase inhibitory activity of compounds 1-3 was performed according to Ellmann et al. ${ }^{19}$ and adapted for a microplate test system, using a volume of $200 \mu \mathrm{l}$ per well. The following solutions were used: sodium phosphate buffer (100 mM, pH 7.4), substrate (acetylthiocholine iodide $7.5 \mathrm{~mm}$ in sodium phosphate buffer), reagent (5,5-dithio-bis-2-nitrobenzoic acid, $10 \mathrm{~mm}$ in sodium phosphate buffer) and enzyme (human acetylcholinesterase (Sigma C1682, Taufkirchen, Germany) $200 \mathrm{U}$ in $2 \mathrm{ml}$ aqua bidest.). First, the absorbance of the suspension containing compound $(10 \mu \mathrm{M})$, buffer $(100 \mathrm{~mm})$, enzyme $(10 \mathrm{mU})$ and reagent $(150 \mu \mathrm{M})$ was determined at $412 \mathrm{~nm}$ (blank). The reaction was started by the addition of the substrate $(140 \mu \mathrm{M})$. After an incubation period of $5 \mathrm{~min}$ at $30^{\circ} \mathrm{C}$, the absorbance was measured at $412 \mathrm{~nm}$ (final value). The activity was calculated by the difference of the final value and the blank. (-)-Huperazine A ( $1 \mu \mathrm{M}$ and $0.1 \mu \mathrm{M})$ was used as the positive control. ${ }^{20}$

Analysis of the effect of compounds 1-3 on human recombinant cAMPspecific PDE-4B2 was carried out by adding $10 \mu \mathrm{M}$ of the compound in $50 \mathrm{~mm}$ Tris- $\mathrm{HCl}$ buffer ( $\mathrm{pH} 7.5$ ), containing $8.3 \mathrm{mM} \mathrm{MgCl}_{2}, 1.7 \mathrm{~mm}$ EGTA and $5 \mathrm{U}$ recombinant human cAMP-specific PDE-4B2 (Biocat 60042-BPS, Heidelberg, Germany) in a volume of $30 \mu \mathrm{l}$ per well. The reaction was started with $10 \mu \mathrm{l}$ of $12 \mu \mathrm{m}$ cAMP (Sigma A9501) dissolved in $50 \mathrm{~mm}$ Tris- $\mathrm{HCl}$ buffer ( $\mathrm{pH} 7.5$ ) containing $8.3 \mathrm{~mm} \mathrm{MgCl}_{2}$ and $1.7 \mathrm{~mm}$ EGTA. After an incubation period of $30 \mathrm{~min}$ at $30^{\circ} \mathrm{C}$, the reaction was stopped and the AMP concentration quantified using a PDELight HTS cAMP Phosphodiesterase Assay Kit (Lonza LT07-600, Wuppertal, Germany) according to the instructions of the supplier. The luminescence was measured using the microtiter plate reader Infinite M200 (Tecan, Crailsheim, Germany) with $0.1 \mathrm{~s}$ integration time. For inhibition of the PDE-4B2, 1 and $10 \mu \mathrm{M}$ of rolipram (4-(3-(cyclopentyloxy)-4-methoxyphenyl)2-pyrrolidinone; Merck Bioscience Cat. No. 557330, Darmstadt, Germany) were used as positive controls.

\section{ACKNOWLEDGEMENTS}

BY Kim gratefully acknowledges receipt of an Overseas Research Scholarship and an International Postgraduate Scholarship from Newcastle University. SE Helaly thank the Egyptian government for a scholarship and mission at TU Berlin. Professor JF Imhoff, Dr H Zinecker and Dr J Wiese are grateful to the Ministry of Science, Economic Affairs and Transport of the State of Schleswig-Holstein (Germany) for supporting the Kieler Wirkstoff-Zentrum in the frame of the 'Future Program for Economy', which is co-financed by the European Union (EFRE).
1 Nachtigall, J. et al. Benzoxacystol, a benzoxazine-type enzyme inhibitor from the deep-sea strain Streptomyces sp. NTK 935. J. Antibiot. (e-pub ahead of print 20 April 2011; doi:10.1038/ja.2011.26).

2 Goodfellow, M. \& Fiedler, H. P. A guide to successful bioprospecting: informed by actinobacterial systematics. Antonie van Leeuwenhoek 98, 119-142 (2010).

$3 \mathrm{Xu}, \mathrm{C}$. et al. Neurotolerant acidophilic Streptomyces species isolated from acidic soils in China: Streptomyces guanduensis sp. nov., Streptomyces paucisporeus sp. nov., Streptomyces rubidus sp. nov. and Streptomyces yanglinensis sp. nov. Int. J. Syst. Evol. Microbiol. 56, 1109-1115 (2006).

4 Fiedler, H. P. Biosynthetic capacities of actinomycetes. 1. Screening for novel secondary metabolites by HPLC and UV-visible absorbance libraries. Nat. Prod. Lett. 2, 119-128 (1993).

5 Williams, S. T., Goodfellow, M. \& Alderson, G. Genus Streptomyces Waksman and Henrici 1943, 339AL In Bergey's Manual of Systematic Bacteriology Vol. 4 (ed Williams, S. T. et al.) 2452-2492 (Williams \& Wilkins, Baltimore, 1989).

6 Haskell, T. H., Ryder, A. \& Bartz, Q. R. Elaiomycin, a new tuberculostatic antibiotic; isolation and chemical characterization. Antibiot. Chemother. 4, 141-144 (1954).

7 Helaly, S. E., Pesic, A., Fiedler, H.- P. \& Süssmuth, R. D. Elaiomycins B and C: alkylhydrazide antibiotics from Streptomyces sp. BK 190. Org. Lett. 13, 1052-1055 (2011).

8 Schneemann, I. et al. Mayamycin, a cytotoxic polyketide from a Streptomyces strain isolated from the marine sponge Halichondria panacea. J. Nat. Prod. 73, 1309-1312 (2010).

9 McGahren, W. J. \& Kunstmann, M. P. A novel $\alpha, \beta$-unsaturated azoxy-containing antibiotic. J. Am. Chem. Soc. 91, 2808-2810 (1969).

10 Nakayama, M. et al. Organism, fermentation, isolation, physico-chemical properties and biological properties. J. Antibiot. 42, 1535-1540 (1989).

11 Fujiu, M. et al. Azoxybacilin, a novel antifungal agent produced by Bacillus cereus NR2991. Production, isolation and structure elucidation. J. Antibiot. 47, 833-835 (1994).

12 Yamato, M. et al. Isolation and properties of valanimycin, a new azoxy antibiotic. J. Antibiot. 39, 184-191 (1986).

13 Omura, S. et al. Jietacins A and B, new nematicidal antibiotics from Streptomyces sp. Taxonomy, isolation, and physico-chemical properties. J. Antibiot. 40, 623-629 (1987).

14 Levenberg, B. Structure and enzymatic cleavage of agaritine, a new phenylhydrazide of L-glutamic acid isolated from Agaricaceae. J. Am. Chem. Soc. 83, 503-504 (1961).

15 List, P. H. \& Luft, P. Gyromitrin, das Gift der Frühjahrslorchel. Arch. Pharm. 301, 294-305 (1968).

16 Kim, S. B., Seong, C. N., Jeon, S. J., Bae, K. S. \& Goodfellow, M. Taxonomic study on neutrotolerant acidophilic actinomycetes isolated from soil and description of Streptomyces yeochonensis sp. nov. Int. J. Syst. Evol. Microbiol. 54, 211-214 (2004).

17 Tamura, K., Dudley, J., Nei, M. \& Kumar, S. MEGA4: molecular evolutionary genetics analysis (MEGA) software version 4.0. Mol. Biol. Evol. 24, 1596-1599 (2007).

18 Saitou, N. \& Nei, M. The neighbour-joining method: a new method for reconstructing phylogenetic trees. Mol. Biol. Evol. 4, 406-425 (1987).

19 Ellmann, G. L., Courtney, K. D., Andres, V. Jr. \& Featherstone, R. M. A new and rapid colorimetric determination of acetylcholinesterase activity. Biochem. Pharmacol. 7, 88-95 (1961).

$20 \mathrm{Di}$ Giovanni, S. et al. In vitro screening assays to identify natural or synthetic acetylcholinesterase inhibitors: thin layer chromatography versus microplate methods. Eur. J. Pharmac. Sci. 33, 109-119 (2008). 